\title{
DIPHTHERITIC MYOCARDITIS: CASE SERIES IN THE PRESENT ERA OF UNIVERSAL IMMUNIZATION PROGRAMME
}

\author{
Anjali Bharani, Hemant Jain. \\ Department of Paediatrics, Mahatma Gandhi Memorial Medical College and MY Hospital, Indore, Madhya \\ Pradesh, India.
}

\begin{abstract}
Diphtheria continues to be reported from the developing world and is a major preventable disease of childhood with high morbidity and mortality. It can affect many organ systems but the cardiovascular involvement in the form of myocarditis carries a high mortality. We report a case series of eight children with the diagnosis of diphtheria who presented with arrhythmias or cardiogenic shock suggestive of severe myocardial damage. Out of eight children, five $(62.5 \%)$ died. Early detection, careful monitoring and aggressive management may result in improved outcomes in these critically sick children.
\end{abstract}

\author{
ARTICLE HISTORY \\ Received 10 February 2020 \\ Accepted 3 June 2020
}

\section{KEYWORDS}

Diphtheria, cardiac, unimmunized

\section{Introduction}

Diphtheria is an acute infectious disease caused by the exotoxin producing strains of Corynebacterium diphtheria. C. diphtheriae is an aerobic gram-positive pleomorphic bacillus. ${ }^{1}$ Throughout history, diphtheria has been one of the most dreaded infectious diseases globally causing epidemics and high mortality amongst children. Due to the availability of effective vaccination, diphtheria has shown a declining trend world over. ${ }^{2}$ However, it remains a significant health concern in countries with poor routine immunization coverage. And it still continues to be reported from the developing countries. ${ }^{3,4,5,6}$ From 2011-2015, India had the largest number of reported cases (18350) followed by Indonesia and Madagascar (3203 and 1633 respectively). ${ }^{2}$ Hospital-based surveillance studies, as well as diphtheria outbreaks published in the last 20 years (1996-2016), indicate that diphtheria cases are frequent among school-going children and adolescents. ${ }^{7}$ As per the national level health surveys, coverage of three doses of diphtheria vaccination was $80 \%$ during 2015-2016. Information about coverage of diphtheria boosters is not routinely collected through these surveys but is expected to be low. ${ }^{8}$ There have been reports of outbreaks of diphtheria from a few states namely Assam (2010), Karnataka (2011), Andhra Pradesh (2014). ${ }^{7}$

Diphtheria can affect many systems and cardiovascular involvement is a major contributor to mortality. Arrhythmias, heart blocks and cardiogenic shock are the manifestations of severe myocardial damage. ${ }^{9}$ There is a scarcity of literature describing these manifestations and very few studies have been reported from central

CONTACT Dr. Anjali Bharani

Email: dr.anjalibharani@gmail.com

Address for Correspondence: Dr. Anjali Bharani (Associate Professor), Department of Pediatrics, Mahatma Gandhi Memorial Medical College and M.Y Hospital Indore, Madhya Pradesh, India.

(C)2020 Pediatric Oncall
India regarding this disease. ${ }^{10}$ Hence, we did a retrospective study of children admitted with diphtheria who presented with cardiac complications to the pediatric intensive care unit (PICU).

\section{Methods \& Materials}

We conducted a retrospective observational study in the Department of Paediatrics at a tertiary care teaching institute from central India. Institutional Ethics committee approval was taken before the commencement of the study. Data was collected from the in-patient records of the patients retrieved from the Medical Records Department. The pediatric cases admitted within the study duration period of 4 months from August 2018 to November 2018 with the diagnosis of diphtheria with myocardial involvement were enrolled in the study. The diagnosis of diphtheria was made clinically on the basis of classic clinical findings of fever, throat pain, white membrane in the throat that bled on touching. ${ }^{11}$ The diagnosis of myocarditis was made on the basis of symptoms and signs of cardiac failure or arrhythmias or electrocardiographic (ECG) findings in the form of conduction abnormalities (heart block) or arrhythmias. ${ }^{11}$ ECG was done in all patients; however, echocardiography could be done only in one patient. Children with other causes of myocardial dysfunction were excluded from the study.

The details of demography, clinical history and examination findings, immunization status, family history, ECG/ Echocardiography findings, laboratory investigations in the form of complete blood count, renal function tests and throat swab smear examination by Albert's stain and treatment given were recorded. Leucocytosis was defined as total leucocyte count more than 15,500/cumm (Age: 4-7 years) and 13,500/cumm (Age: 8-13 years). Hypotension was defined as systolic BP $<2$ SD below normal for age. ${ }^{11}$ The identity of the patients was not revealed in the study. Data was tabulated and analyzed.

\section{Results}

A total of eight patients were enrolled during the study period of four months. Male to female ratio was 
equal. Mean age was 8.75 years. In all patients, the history of immunization was either incomplete or none. History of high-grade fever was present in all patients. Bull neck was present in all except one patient. On throat examination, white membrane was present in all cases. It caused airway obstruction in one case. Neurological involvement in the form of palatal palsy and nasal twang of voice was present in three patients. All patients had leucocytosis on complete blood count except one and deranged renal function test were seen in two patients. All the patients had cardiac complications after 5 to 7 days of illness. Clinically they presented with either arrhythmia, bradycardia/ tachycardia, hypotension, and breathlessness. Bacteria (Klebs-Loeffler bacillus KLB) was isolated on throat swab smear examination by Albert's stain in two cases. Mean duration of hospital stay was 7 days. Out of 8 children, $5(62.5 \%)$ died. Four patients succumbed within 24 hours of admission. All patients received antidiphtheritic serum $(40,000-1,00,000$ IU) intravenously, erythromycin ( $40-50 \mathrm{mg} / \mathrm{kg} /$ day) orally in 4 divided doses, and intravenous fluids, if needed inotropes in the form of dobutamine $(10 \mathrm{mcg} / \mathrm{kg} / \mathrm{min})$, ventilation and defibrillation. Still, 5 patients could not be salvaged. Clinical and laboratory features are tabulated in table 1. Patient 1 , in addition, had multiple ventricular thrombi for which anticoagulation therapy was given in the form of low molecular weight heparin $1 \mathrm{mg} / \mathrm{kg} / \mathrm{dose}$ subcutaneous twice daily initially for 5 days later shifted to oral warfarin $(0.05 \mathrm{mg} / \mathrm{kg} /$ day $)$ in 2 divided doses till resolution of thrombi ( 2 weeks).

\section{Discussion}

The pharyngo-tonsillar is the classic presentation of diphtheria characterized by sore throat, fever, pseudomembrane, cervical Iymphadenopathy/ bull neck appearance, dysphagia, drooling. ${ }^{12}$ The bacteria produce a powerful exotoxin, responsible for its virulence. Toxin mediated inhibition of protein synthesis is reported as a mechanism of all systemic manifestations. ${ }^{13}$ Degenerative changes in tissues, which include heart, muscle, peripheral nerves,

Table 1. Clinical features and investigations of patients admitted with diphtheria

\begin{tabular}{|c|c|c|c|c|c|c|c|c|}
\hline & Patient 1 & Patient 2 & Patient 3 & Patient 4 & Patient 5 & Patient 6 & Patient 7 & Patient 8 \\
\hline Age (years) & 5 & 13 & 3 & 11 & 7 & 13 & 8 & 10 \\
\hline Gender & Female & Male & Female & Female & Female & Male & Male & Male \\
\hline $\begin{array}{l}\text { Day of } \\
\text { presentation } \\
\text { of myocardial } \\
\text { involvement } \\
\text { after illness }\end{array}$ & $7^{\text {th }}$ & $7^{\text {th }}$ & $5^{\text {th }}$ & $5^{\text {th }}$ & $4^{\text {th }}$ & $5^{\text {th }}$ & $5^{\text {th }}$ & $7^{\text {th }}$ \\
\hline $\begin{array}{l}\text { Clinical } \\
\text { Features }\end{array}$ & $\begin{array}{l}\text { Fever, } \\
\text { Bull neck, } \\
\text { Membrane } \\
\text { in throat, } \\
\text { Nasal } \\
\text { twang }\end{array}$ & $\begin{array}{l}\text { Fever, } \\
\text { Bull neck, } \\
\text { Membrane } \\
\text { in throat, } \\
\text { Palatal } \\
\text { Palsy }\end{array}$ & $\begin{array}{l}\text { Fever, } \\
\text { Bull neck, } \\
\text { Membrane } \\
\text { in throat }\end{array}$ & $\begin{array}{l}\text { Fever, } \\
\text { Membrane } \\
\text { in throat }\end{array}$ & $\begin{array}{l}\text { Fever, } \\
\text { Bull neck, } \\
\text { Membrane } \\
\text { in throat, } \\
\text { Airway } \\
\text { obstruction }\end{array}$ & $\begin{array}{l}\text { Fever, } \\
\text { Bull neck, } \\
\text { Membrane } \\
\text { in throat, } \\
\text { Nasal } \\
\text { twang }\end{array}$ & $\begin{array}{l}\text { Fever, } \\
\text { Bull neck, } \\
\text { Membrane } \\
\text { in throat }\end{array}$ & $\begin{array}{l}\text { Fever, } \\
\text { Bull neck, } \\
\text { Membrane } \\
\text { in throat, } \\
\text { Aphonia }\end{array}$ \\
\hline ECG Findings & $\begin{array}{l}\text { Complete } \\
\text { Heart } \\
\text { Block }\end{array}$ & $\begin{array}{l}\text { Escape } \\
\text { ventricular } \\
\text { Rhythm }\end{array}$ & $\begin{array}{l}\text { Sudden } \\
\text { Ventricular } \\
\text { tachycardia }\end{array}$ & $\begin{array}{l}\text { Left } \\
\text { Bundle } \\
\text { branch } \\
\text { block type } \\
\text { ventricular } \\
\text { tachycardia }\end{array}$ & $\begin{array}{l}\text { Sinus } \\
\text { tachycardia }\end{array}$ & $\begin{array}{l}\text { Sinus } \\
\text { bradycardia }\end{array}$ & $\begin{array}{l}\text { Ventricular } \\
\text { tachycardia } \\
\text { with } \\
\text { capture } \\
\text { beats }\end{array}$ & $\begin{array}{l}\text { Sinus } \\
\text { tachycardia }\end{array}$ \\
\hline $\begin{array}{l}\text { WBC count } \\
\text { (cells/cumm) }\end{array}$ & 34,900 & 14000 & 25000 & 40000 & 13983 & 14000 & 30800 & 26000 \\
\hline $\begin{array}{l}\text { Urea/ } \\
\text { Creatinine } \\
(\mathrm{mg} / \mathrm{dl})\end{array}$ & $35 / 0.8$ & $213 / 0.5$ & $28 / 0.4$ & $34 / 0.7$ & $26 / 0.8$ & $30 / 0.5$ & $77 / 1.63$ & $38 / 0.46$ \\
\hline $\begin{array}{l}\text { Throat Swab } \\
\text { positive for } \\
\text { diphtheria } \\
\text { bacillus }\end{array}$ & No & No & No & No & Yes & No & No & Yes \\
\hline Immunization & Incomplete & Incomplete & $\begin{array}{l}\text { Not } \\
\text { Known }\end{array}$ & Incomplete & Incomplete & $\begin{array}{l}\text { Not } \\
\text { Known }\end{array}$ & Incomplete & $\begin{array}{l}\text { Not } \\
\text { Known }\end{array}$ \\
\hline Outcome & Survived & Died & Died & Died & Survived & Survived & Died & Died \\
\hline $\begin{array}{l}\text { Duration of } \\
\text { Hospital Stay } \\
\text { (Days) }\end{array}$ & 23 & 1 & 11 & 1 & 8 & 12 & 1 & 1 \\
\hline
\end{tabular}


adrenals, kidneys, liver and spleen result in systemic pathology of the disease. ${ }^{14}$ The cardio-vascular involvement leads to the highest mortality as compared to other system involvement. Myocarditis occurs in $10-20 \%$ of all diphtheria patients. ${ }^{15}$ Few Indian studies done on diphtheria report incidence of $16-66 \%$ of myocarditis in cases of diphtheria. ${ }^{16,17}$ Our study had similar mortality of $62.5 \%$. Myocardial dysfunction as well as bradyarrhythmia and tachyarrhythmia are common but the most dreaded one is the complete heart block and ventricular tachycardia which are fatal in almost all cases. Ventricular tachycardia occurs in later stages of illness and is usually refractory and all the patients who developed this arrhythmia in our series died. Conduction system abnormalities are a marker of severe damage and pacing does not help much. ${ }^{18}$ Elevated renal function tests are indicators of advanced disease and seen in all cases who died. ${ }^{9}$ Hence are a poor prognostic marker. Lack of early identification and treatment leads to high mortality in diphtheritic myocarditis.

Anti-toxin administration forms the mainstay of treatment, but it has limited action against penetrating toxins or toxin already absorbed inside the cells. Hence it does not help much in cases presenting in advanced stage of the disease. ${ }^{11}$ The role of immunosuppressive agents such as steroids and immunoglobulins are not approved. ${ }^{19,20}$ Hence we did not use it in any of our patients. Proper airway management, supportive measures like inotropes, oxygen, and temporary pacemaker insertion may improve survival in critical cases of severe myocardial damage.

\section{Limitations:}

This case series describes only 8 patients. The organism was isolated in only two cases. Pacemaker insertion and ECMO facilities were not available to critically ill patients with cardiogenic shock and complete heart block that could improve outcomes.

\section{Conclusion}

Diphtheritic myocarditis has a high mortality (60\%). Such patients require monitoring in pediatric cardiac intensive care units to enable early detection of serious arrhythmias like ventricular tachycardia and complete heart block so that timely treatment can be provided. It highlights the urgent need to fill the gaps in the universal immunization programme and ensure complete immunization of children.

\section{Compliance with Ethical Standards \\ Funding: None \\ Conflict of Interest: None}

\section{References}

1. Winn W, Allen S, Janda W, Koneman E, Procop G, Schreckenberger $P$, Woods $G$. Corynebacterium species. In: Koneman's Color Atlas and Textbook of Diagnostic Microbiology. 6th ed. Philadelphia: Lippincott Williams \& Wilkins. 2006: 803-7

2. World Health Organization (WHO). Diphtheria vaccine: WHO position paper. Weekly Epidemiological Record. 2017; 92:417 - 435.

3. Singh J, Harit AK, Jain DC, Panda RC, Tewari KN, Bhatia
$\mathrm{R}$, et al. Diphtheria is declining, but continues to kill many children: Analysis of data from a sentinel centre in Delhi, 1997. Epidemiol Infect.1999;123:209-15.

4. Lodha R, Dash NR, Kapil A, Kabra SK. Diphtheria in urban slums in north India. Lancet. 2000; 355:204.

5. Anima H, Malay M, Santanu H, Rajashree R, Sita C, Baran SA. A study on determinants of occurrence of complications and fatality among diphtheria cases admitted to ID and BG hospital of Kolkata. J Commun Dis. 2008; 40:53-8.

6. Ornek E, Ureyen CM, Kurtul A, Oksüz F. Diphtheria myocarditis in Turkey after years. Anadolu Kardiyol Derg. 2012; 12:279-80.

7. Murhekar M. Epidemiology of Diphtheria in India, 19962016: Implications for prevention and control. Am J Trop Med Hyg. 2017; 97:313-18.

8. National family health survey (NFHS-4) 2015-16, 2016. Mumbai: International Institute for Population Sciences (IIPS) and Macro International. Available at http://www. rchiips.org/nfhs/nfhs4.shtml. Accessed on 31.5.20

9. Verghese MJ, Ramakrishanan S, Kothari SS, Parashar $A P$, Juneja R, Saxsena A. Complete heart block due to diphtheritic myocarditis in the present era. Ann Pediatr Cardiol. 2013;6(1):34-8.

10. Meshram RM, Patil A. Clinical profile and outcome of diphtheria in central India: a retrospective observational study. Int J Contemp Pediatr. 2018; 5:1600-5

11. Buescher ES. Diphtheria (Corynebacterium diphtheriae) In: Kliegman RM, Stanton BF, Schor NF, St Geme JW, Behrman $\mathrm{RE}$, editors. Nelson textbook of Pediatrics. 20th ed. Vol. 1. Philadelphia, PA: Elsevier; 2016. pp. 1345-8.

12. American Academy of Pediatrics. Diphtheria In: Pickering LK, Baker CJ, Kimberlin DW, Long SS. (eds). Red Book: 2012 Report of the Committee on Infectious Diseases. 29th ed. Elk Grove Village, IL: American Academy of Pediatrics. 2012: 307-11.

13. Collier RJ. Diphtheria toxin: Mode of action and structure. Bacteriol Rev. 1975; 39:54-85.

14. Samuelson J. Infectious Diseases. In Cotran RS, Kumar V, Collins T (eds). Robbins Pathologic basis of diseases. 6th ed. Singapore. WB Saunders. 1999. pp 329-75

15. Hoyne A, Welfor N. Diphtheritic myocarditis, a review of 496 cases. J Pediatr. 1934; 5:642-53

16. Jayashree $M$, Shruthi N, Singhi S. Predictors of outcome in patients with diphtheria receiving intensive care. Indian Pediatr. 2006; 43:155-60.

17. Havaldar PV, Sankpal MN, Doddannavar RP. Diphtheritic myocarditis: Clinical and laboratory parameters of prognosis and fatal outcome. Ann Trop Paediatr. 2000; 20:209-15.

18. Stockins BA, Lanas FT, Saavedra JG, Opazo JA. Prognosis in patients with diphtheric myocarditis and bradyarrhythmia: assessment of results of ventricular pacing. $\mathrm{Br}$ Heart $\mathrm{J}$. 1994; 72:190-1.

19. Thisyakorn U, Wongvanich J, Kumpeng V. Failure of corticosteroid therapy to prevent diphtheritic myocarditis or neuritis. Pediatr Infect Dis. $1984 ; 3: 126-8$.

20. Mason JW, O'Connell JB, Herskowtz A, Rose NR, McManus BM, Billingham ME, et al. A clinical trial of immunosuppressive therapy for myocarditis. The myocarditis treatment trial investigators. N Engl J Med. 1995;3(333):269-75. 